\title{
PENGARUH PANDEMI COVID 19 TERHADAP KUNJUNGAN IMUNISASI DI POSYANDU DESA TANJUNGWANGI KECAMATAN CIJAMBE \\ TAHUN 2020
}

\section{THE EFFECT OF COVID 19 PANDEMIC ON IMMUNIZATION VISIT IN POSYANDU} VILLAGE TANJUNGWANGI KECAMATAN CIJAMBE IN 2020

\author{
Nicke Uriant Diharja ${ }^{1}$ \\ ${ }^{1}$ Universitas Nasional Prodi DIV Kebudanan, Jakarta \\ email : nickeuriant4@gmail.com \\ Siti syamsiah ${ }^{2}$ \\ ${ }^{2}$ Universitas Nasional Prodi DIV Kebudanan, Jakarta \\ email : sitisyamsiah09@gmail.com \\ Risza choirunnisa ${ }^{3}$ \\ ${ }^{3}$ Universitas Nasional Prodi DIV Kebudanan, Jakarta \\ email : risza.choirunnisa@gmail.com
}

*Coresponding Author: sitisyamsiah09@gmail.com

\section{ABSTRAK}

Latar Belakang: Masa Pandemi Covid-19 adalah masa yang sangat mengkawatirkan, khususnya bagi para ibu yang memiliki anak balita. Sementara itu, imunisasi sangat penting bagi anak-anak balita guna mencegah berbagai penyakit berbahaya. Dimasa Pandemi Covid-19, para tenaga kesehatan tetap mensosialisasikan imunisasi kepada para ibu, walaupun hasilnya di tahun 2019 partisipan imunisasi menurun tajam. Pada Tahun 2019, di UPTD Puskesmas Tanjungwangi, Kecamatan Cijambe cakupan imunisasi turun menjadi hanya 64\%. Hal tersebut menjadi rentan terhadap ketahanan kesehatan balita terhadap berbagai penyakit yang berbahaya.

Tujuan: Mengetahui pengaruh pandemi Covid-19 terhadap partisipasi kunjungan imunisasi di Posyandu Tanjungwangi Puskesmas Tanjungwangi Kecamatan Cijambe.

Metodologi: Penelitian cross sectional dengan teknik survey elektronik. Sampel berjumlah 78 ibu yang meemiliki anak umur 0-24 bulan yang jumlahnya ditetapkan dengan rumus Slovin. Pengambilan sampel menggunakan purposive sampling. Instrumen penelitian terdiri dari instrumen pengetahuan, sikap ibu, dan dukungan 
keluarga yang disebarkan secara online. Data dianalisis menggunakan uji ChiSquare.

Hasil Penelitian: Tidak ada pengaruh pengetahuan ibu ( $p$-value $=0,468)$, sikap ibu ( $p$-value $=0,667)$, dan dukungan keluarga ( $p$-value $=0,626)$ terhadap partisipasi ibu dalam kunjungan imunisasi di Posyandu Tanjungwangi, Desa Tanjungwangi, Kecamatan Cijambe Tahun 2020.

Kesimpulan dan Saran: Tidak ada pengaruh Pandemi Covid-19 terhadap kunjungan imunisasi di Posyandu Tanjungwangi, Desa Tanjungwangi, Kecamatan Cijambe Tahun 2020. Saran: Ibu-ibu yang memiliki balita hendaknya tetap memberikan imunisasi bagi anaknya walaupun dalam kondisi Pandemi Covid-19 dengan tetap mengikiti arahan tenaga kesehatan.

Kata Kunci: Pandemi Covid-19, pengetahuan, sikap, dukungan keluarga, kunjungan imunisasi

\section{ABSTRACT}

Background: The Covid-19 Pandemic period was a very worrying period, especially for mothers with children under five. Meanwhile, immunization is very important for children under five to prevent various dangerous diseases. In the Pandemic Covid-19 era, health workers continued to socialize immunizations with mothers, even though the results in 2019 immunization participants declined sharply. In 2019, in the UPTD Puskesmas Tanjungwangi, Cijambe District immunization coverage fell to only 64\%. This becomes vulnerable to the health resilience of children under five against various dangerous diseases.

Objective: To determine the effect of the Covid-19 pandemic on the participation of immunization visits at the Tanjungwangi Health Center in Tanjungwangi, Cijambe District. 
Methodology: Cross sectional research with electronic survey techniques. The sample consisted of 78 mothers who had children aged 0-24 months whose numbers were determined by the Slovin formula. Sampling using purposive sampling. The research instrument consisted of instruments of knowledge, mother's attitudes, and family support that was disseminated online. Data were analyzed using Chi-Square test.

Results: There was no effect of maternal knowledge ( $p$-value $=0.468$ ), maternal attitudes ( $p$-value $=0.667$ ), and family support $(p$-value $=0.626$ ) on maternal participation in immunization visits at the Poswandu Tanjungwangi, Tanjungwangi Village, District Cijambe in 2020.

Conclusions and Suggestions: There is no influence of the Covid-19 Pandemic on immunization visits in the Tanjungwangi Posyandu, Tanjungwangi Village, Cijambe District in 2020. Suggestions: Mothers who have children under five should continue to provide immunization for their children even in the condition of the Covid-19 Pandemic while maintaining referral of health workers.

Keywords: Covid-19 pandemic, knowledge, attitudes, family support, immunization visits

\section{PENDAHULUAN}

Imunisasi merupakan upaya kesehatan masyarakat paling efektif dan efisien dalam mencegah beberapa penyakit berbahaya. Dalam imunisasi terdapat konsep Herd Immunity atau Kekebalan Kelompok. Kekebalan Kelompok ini hanya dapat terbentuk apabila cakupan imunisasi pada sasaran tinggi dan merata di seluruh wilayah. Konsep ini merupakan bukti bahwa program imunisasi sangat efektif juga efisien karena hanya dengan menyasar kelompok rentan maka seluruh masyarakat akan dapat terlindungi. (Yurianto, 2020).

Masa pandemi COVID-19 yang telah menjangkiti sebagian besar negara pun hendaknya tidak menyurutkan semangat tenaga kesehatan untuk tetap 
menggaungkan pentingnya imunisasi dan melakukan langkah-langkah penting untuk memastikan setiap anak yang merupakan kelompok rentan terlindungi dari penyakit-penyakit berbahaya dengan imunisasi. Pelayanan imunisasi pada masa pandemi COVID-19 dilaksanakan sesuai kebijakan pemerintah daerah setempat, berdasarkan analisis situasi epidemiologi penyebaran COVID-19, cakupan imunisasi rutin, dan situasi epidemiologi PD3I. Petugas kesehatan diharapkan dapat memantau status imunisasi setiap sasaran yang ada di wilayah kerjanya. (Yurianto, 2020).

Pada tahun 2017 sebanyak 22,93\% bayi di Kabupaten Subang tidak mendapatkan Imunisasi Dasar Lengkap, pada tahun 2018 jumlah bayi yang tidak mendapat Imunisasi Dasar Lengkap mengalami penurunan sebesar 10,37\% dan pada tahun 2019 kembali mengalami peningkatan jumlah bayi yang tidak mendapatkan Imunisasi Dasar Lengkap sebesar 71,89\%. Gambaran cakupan imunisasi di Kabupaten Subang dengan target cakupan nasional menunjukan bahwa cakupan di Kabupaten Subang masih rendah atau belum sesuai dengan target cakupan nasional (Dinkes Kabupaten Subang, 2019).

UPTD Puskesmas Tanjungwangi yang merupakan salah satu Puskesmas yang ada di Kabupaten Subang dari 40 Puskesmas yang ada, cakupan imunisasi Puskesmas Tanjungwangi masih di bawah standar Dinas Kesehatan Kabupaten Subang. Cakupan imunisasi campak di Puskesmas Tanjungwangi sebesar 90,8\%, pada cakupan Imunisasi DPT-HB-Hib 8,55\% sedangkan pada cakupan imunisasi Hepatitis B sebesar 5,3\%. Setelah adanya pandemi Covid-19 ternyata cakupan kunjungan partisipasi imunisasi menurun. Pada Desember 2019 jumlahnya ada 79\% sedangkan setelah adanya pandemic Covid-19 menjadi 64\% (Dinkes Kabupaten Subang, 2019).

Adanya kasus tersebut, jika tidak segera diatasi akan berdampak dengan meningkatnya kasus Kejadian Luar Biasa (KLB) serta penyebaran penakit akan semakin cepat, apalagi pada saat ini ditengah pandemi Covid-19 yang menyebabkan pembatasan beraktivitas tentu berdampak pada partisipasi kunjungan imunisasi di Posyandu.

Berdasarkan adanya permasalahan tersebut, penelitian guna mengetahui bagaimana pengaruh pandemi Covid-19 terhadap partisipasi kunjungan imunisasi di 
Posyandu Tanjungwangi Puskesmas Tanjungwangi Kecamatan Cijambe tahun 2020 sangat diperlukan.

\section{METODE PENELITIAN}

Metode penelitian adalah penelitian kuantitatif dengan jenis penelitian cross sectional dan dengan teknik survey elektronik. Populasi dalam penelitian ini adalah Ibu yang memiliki bayi dan balita 0-24 bulan yang masih mendapatkan imunisassi di Posyandu Desa Tanjungwangi Kecamatan Cijambe yang berjumlah 362, dan dari populasi tersebut diambil sampel sebanyak 78 ibu yang jumlahnya ditetapkan dengan rumus Slovin. Pengambilan sampel menggunakan purposive sampling. Instrumen penelitian terdiri dari instrumen pengetahuan, sikap ibu, dan dukungan keluarga yang disebarkan secara online dengan menggunakan kuesioner yang dibuat menggunakan Formulir Google. Data dianalisis menggunakan uji Chi-Square.

Hasil Penelitian

1. Karakteristik responden

Tabel 1.

Distribusi Frekuensi Karakteristik Responden

\begin{tabular}{lcc}
\hline \multirow{2}{*}{ Karakteristik Responden } & \multicolumn{2}{c}{ Distribusi Frekuensi } \\
\cline { 2 - 3 } & $\mathrm{F}$ & Persentase (\%) \\
\hline Pendidikan : & 18 & 23,10 \\
SMP & 32 & 41,00 \\
SMA & 28 & 36,90 \\
Sarjana D3/S1 & & \\
\hline Pekerjaan : & 16 & 66,70 \\
Ibu Rumah Tangga (IRT) & 3 & 7,70 \\
Swasta & 11 & 9,00 \\
Pegawai Negeri Sipil (PNS) & 21 & 16,70 \\
Lain-lain & & \\
\hline
\end{tabular}


Asian Research Midwifery and Basic Science Journal e-ISSN: 2723-6463

ARIABD

\begin{tabular}{lll}
\hline \multirow{2}{*}{ Karakteristik Responden } & \multicolumn{2}{l}{ Distribusi } \\
\cline { 2 - 3 } & $\mathrm{F}$ & Prekuensi \\
\hline Total & 78 & 100,00 \\
\hline
\end{tabular}

Sumber: Hasil Pengolahan Dat

Berdasarkan Tabel 1,di atas, untuk karakteristik pendidikan responden, responden dengan pendidikan SMP yaitu sebanyak 18 responden (23,10\%), pendidikan SMA sebanyak 32 respeonden (41,00\%), dan pendidikan Sarjana (D3/S1) sebanyak 28 responden (36,90\%). Selanjutnya, untuk karakteristik pekerjaan, responden dengan pekerjaan sebagai Ibu Rumah Tangga yaitu sebanyak 52 orang (66,7\%), bekerja di Swasta sebanyak 6 responden (7,7\%), PNS sebanyak 7 orang (9,0\%), pekerjaan lain-lain sebanyak 13 respeonden $(16,7 \%)$.

\section{Analisis univariat}

Tabel 2.

Distribusi Frekuensi Partisipasi Ibu dalam Kunjungan Imunisasi di Posyandu Tahun 2020

\begin{tabular}{llc}
\hline \multirow{2}{*}{ Partisipasi Ibu dalam Kunjungan Imunisasi } & \multicolumn{2}{l}{ Distribusi Frekuensi } \\
\cline { 2 - 3 } & $\mathrm{F}$ & Persentase (\%) \\
\hline $\mathrm{Ya}$ & 44 & 56,40 \\
Tidak & 34 & 43,60 \\
\hline Total & 78 & 100,00 \\
\hline
\end{tabular}

Sumber: Hasil Pengolahan Data

Berdasarkan Tabel 2. di atas, dari 78 responden sebanyak 44 ibu atau 56,40\% mengikuti atau ikut berpartispasi dalam kunjungan imunisasi di Posyandu tahun 2020. Adapun 34 ibu atau 43,60\% tidak ikut berpartisipasi dalam kunjungan imunisasi di Posyandu tahun 2020.

Tabel 3. 
Asian Research Midwifery and Basic Science Journal e-ISSN: 2723-6463

$\triangle \mathrm{RIABD}$

Distribusi Frekuensi Pengetahuan Ibu tentang Imunisasi di Posyandu Tahun 2020

\begin{tabular}{lcc}
\hline \multirow{2}{*}{ Pengetahuan Ibu } & \multicolumn{2}{c}{ Distribusi Frekuensi } \\
\cline { 2 - 3 } & F & Persentase (\%) \\
\hline Baik & 6 & 7,70 \\
Kurang & 72 & 92,30 \\
\hline Total & 78 & 100,00 \\
\hline
\end{tabular}

Sumber: Hasil Pengolahan Data

Berdasarkan Tabel 3. di atas, dari 78 responden yang diteliti diperoleh hasil bahwa hampir keseluruhannya yaitu sebanyak 72 responden atau 92,30\% ibu-ibu di Posyandu Tahun 2020 kurang memiliki pengetahuan tentang imunisasi. Adapun, sisanya sebanyak 6 responden atau 7,70\% saja responden atau ibu-ibu yang memiliki pengetahuan baik mengenai imunisasi.

Tabel 4.

Distribusi Frekuensi Sikap Ibu terhadap Kunjungan Imunisasi di Posyandu Tahun 2020

\begin{tabular}{llc}
\hline \multirow{2}{*}{ Sikap Ibu } & \multicolumn{2}{l}{ Distribusi Frekuensi } \\
\cline { 2 - 3 } & $\mathrm{F}$ & Persentase (\%) \\
\hline Positif & 13 & 16,70 \\
Negatif & 65 & 83,30 \\
\hline Total & 78 & 100,00 \\
\hline
\end{tabular}

Sumber: Hasil Pengolahan Data

Berdasarkan Tabel 4. di atas, dari 78 responden yang diteliti diperoleh sebagian besar responden memiliki sikap negatif terhadap kunjungan imunisasi di Posyandu tahun 2020, yaitu sebanyak 65 responden atau 83,30\%. Sementara itu, hanya 13 responden atau 16,70\% saja yang sikapnya positif.

Tabel 5.

Distribusi Frekuensi Dukungan Keluarga terhadap Kunjungan Imunisasi di Posyandu Tahun 2020 
Asian Research Midwifery and Basic Science Journal e-ISSN: 2723-6463

$\triangle \mathrm{RIABD}$

\begin{tabular}{lll}
\hline \multirow{2}{*}{ Dukungan Keluarga } & \multicolumn{2}{l}{ Distribusi Frekuensi } \\
\cline { 2 - 3 } & F & Persentase (\%) \\
\hline Mendukung & 34 & 56,67 \\
Tidak Mendukung & 26 & 43,33 \\
\hline Total & 60 & 100,00 \\
\hline
\end{tabular}

Sumber: Hasil Pengolahan Data

Berdasarkan Tabel 5. di atas, dari 78 responden yang diteliti diperoleh sebagian besar responden yang mendapat dukungan dari keluarganya untuk melakukan kunjungan imunisasi di Posyandu tahun 2020 sebanyak 66 responden atau 84,60\%. Adapun, sebanyak 12 responden atau 15,40\% tidak didukung oleh keluarganya untuk melakukan kunjungan imunisasi di Posyandu tahun 2020.

3. Analisis bivariat

Tabel 6.

Pengaruh Pengetahuan terhadap Partisipasi Ibu dalam Kunjungan Imunisasi di Posyandu Tahun 2020

\begin{tabular}{|c|c|c|c|c|c|c|c|c|}
\hline \multirow{3}{*}{ Pengetahuan } & \multicolumn{4}{|c|}{$\begin{array}{l}\text { Partisipasi Ibu dalam Kunjungan } \\
\text { Imunisasi }\end{array}$} & \multirow{2}{*}{\multicolumn{2}{|c|}{ Total }} & \multirow{3}{*}{$\mathrm{p}$-value } & \multirow{3}{*}{ OR } \\
\hline & \multicolumn{2}{|c|}{$\mathrm{Ya}$} & \multicolumn{2}{|c|}{ Tidak } & & & & \\
\hline & $\mathrm{N}$ & $\%$ & $N$ & $\%$ & $n$ & $\%$ & & \\
\hline Baik & 4 & 9,1 & 2 & 5,9 & 6 & 7,7 & 0,468 & - \\
\hline Kurang & 40 & 90,9 & 32 & 94,1 & 72 & 92,3 & & \\
\hline Total & 44 & 100,0 & 34 & 100,0 & 78 & 100,0 & & \\
\hline
\end{tabular}

Sumber: Hasil Pengolahan Data

Hasil penelitian pada Tabel 6. di atas responden yang memiliki pengetahuan yang baik tentang imunisasi dan ikut berpartisipasi dalam kunjungan imunisasi adalah sebanyak 4 orang (9,1\%), sementara ibu yang memiliki pengetahuan kurang tetapi tetap ikut berpartisipasi dalam kunjungan imunisasi sebanyak 40 orang atau 90,1\%. Adapun ibu yang memiliki pengetahuan baik tetapi tidak ikut berpartisipasi dalam kunjungan imunisasi sebanyak 2 orang atau 5,9\%. Selanjutnya, ibu yang pengetahuan imunisasinya kurang dan juga tidak ikut berpartisipasi dalam 
kunjungan imunisasi sebanyak 32 orang atau 94,1\%. Berdasarkan kondisi tersebut, diperoleh nilai p-value sebesar 0,468. Hal tersebut menunjukkan bahwa tidak terdapat pengaruh pengetahuan ibu mengenai imunisasi terhadap partisipasi ibu dalam kunjungan imunisasi di Posyandu Tahun 2020.

Tabel 7.

Pengaruh Sikap Ibu terhadap Partisipasi Ibu dalam Kunjungan Imunisasi di Posyandu Tahun 2020

\begin{tabular}{|c|c|c|c|c|c|c|c|c|}
\hline \multirow{3}{*}{ Sikap } & \multicolumn{4}{|c|}{$\begin{array}{l}\text { Partisipasi Ibu dalam Kunjungan } \\
\text { Imunisasi }\end{array}$} & \multirow{2}{*}{\multicolumn{2}{|c|}{ Total }} & \multirow{3}{*}{$\mathrm{p}$-value } & \multirow{3}{*}{ OR } \\
\hline & \multicolumn{2}{|l|}{$\mathrm{Ya}$} & \multicolumn{2}{|c|}{ Tidak } & & & & \\
\hline & $n$ & $\%$ & $\mathrm{~N}$ & $\%$ & $n$ & $\%$ & & \\
\hline Positif & 6 & 13,6 & 7 & 20,6 & 13 & 16,7 & 0,414 & - \\
\hline Negatif & 38 & 86,4 & 27 & 79,4 & 65 & 83,3 & & \\
\hline Total & 44 & 100,0 & 34 & 100,0 & 78 & 100,0 & & \\
\hline
\end{tabular}

Sumber: Hasil Pengolahan Data

Hasil penelitian pada Tabel 7. di atas, responden yang memiliki sikap yang positif dan ikut berpartisipasi dalam kunjungan imunisasi adalah sebanyak 6 orang $(13,6 \%)$, sementara ibu yang memiliki negatif tetapi tetap ikut berpartisipasi dalam kunjungan imunisasi sebanyak 38 orang atau 86,4\%. Adapun ibu yang memiliki sikap positif tetapi tidak ikut berpartisipasi dalam kunjungan imunisasi sebanyak 7 orang atau 20,6\%. Selanjutnya, ibu yang sikapnya negatif dan juga tidak ikut berpartisipasi dalam kunjungan imunisasi sebanyak 27 orang atau 79,4\%. Berdasarkan kondisi tersebut, diperoleh nilai p-value sebesar 0,667. Hal tersebut menunjukkan bahwa tidak terdapat pengaruh sikap ibu terhadap partisipasi ibu dalam kunjungan imunisasi di Posyandu Tahun 2020.

Tabel 8. 
Pengaruh Dukungan Keluarga terhadap Partisipasi Ibu dalam Kunjungan Imunisasi di Posyandu Tahun 2020

\begin{tabular}{|c|c|c|c|c|c|c|c|c|}
\hline \multirow{3}{*}{ Dukungan Keluarga } & \multicolumn{4}{|c|}{$\begin{array}{l}\text { Partisipasi Ibu dalam Kunjungan } \\
\text { Imunisasi }\end{array}$} & \multirow{2}{*}{\multicolumn{2}{|c|}{ Total }} & \multirow{3}{*}{$\mathrm{p}$-value } & \multirow{3}{*}{ OR } \\
\hline & \multicolumn{2}{|l|}{$\mathrm{Ya}$} & \multicolumn{2}{|c|}{ Tidak } & & & & \\
\hline & $n$ & $\%$ & $\mathrm{~N}$ & $\%$ & $n$ & $\%$ & & \\
\hline Mendukung & 38 & 86,4 & 28 & 82,4 & 66 & 84,6 & 0,626 & - \\
\hline Tidak Mendukung & 6 & 13,6 & 6 & 17,6 & 12 & 15,4 & & \\
\hline Total & 44 & 100,0 & 34 & 100,0 & 78 & 100,0 & & \\
\hline
\end{tabular}

Sumber: Hasil Pengolahan Data

Hasil penelitian pada Tabel 8. di atas, responden yang mendapatkan dukungan keluarga dan ikut berpartisipasi dalam kunjungan imunisasi adalah sebanyak 38 orang $(86,4,6 \%)$, sementara yang tidak mendapat dukungan tetapi tetap ikut berpartisipasi dalam kunjungan imunisasi sebanyak 6 orang atau 13,6\%. Adapun ibu yang mendapat dukungan keluarga tetapi tidak ikut berpartisipasi dalam kunjungan imunisasi sebanyak 28 orang atau 82,4\%. Selanjutnya, ibu yang tidak mendapat dukungan keluarga dan juga tidak ikut berpartisipasi dalam kunjungan imunisasi sebanyak 6 orang atau 17,6\%. Berdasarkan kondisi tersebut, diperoleh nilai p-value sebesar 0,626. Hal tersebut menunjukkan bahwa tidak terdapat pengaruh dukungan keluarga terhadap partisipasi ibu dalam kunjungan imunisasi di Posyandu Tahun 2020.

\section{PEMBAHASAN}

Partisipasi kunjungan imunisasi dari 78 responden sebagian besar yaitu sebanyak 44 ibu atau 56,40\% mengikuti atau ikut berpartispasi dalam kunjungan imunisasi di Posyandu tahun 2020. Pada umumnya ibu-ibu ikut berpartisipasi dalam kunjungan imunisasi di Posyandu yang ada di lingkungannya (Reihana dan Duarsa, 2016).

Aspek karakteristik pendidikan responden, sebagian besar adalah SMA sebanyak 32 respeonden (41,00\%) dan dikuti oleh yang berpendidikan Sarjana (D3/S1) dan SMP. Hasil tersebut menunjukkan bahwa dengan bekal pendidikan yang 
relatif tinggi menjadi bekal mereka memahami tata cara untuk melakukan kunjungan imunisasi di Posyandu ditengah Pandemi Covid-19, yaitu mematuhi Protokoler Kesehatan yang ditetapkan pemerintah

Faktor lainnya adalah karakteristik pekerjaan responden, dari hasil penelitian sebagian besar ibu-ibu adalah berstatus sebagai Ibu Rumah Tangga (IRT) yang mencapai 52 orang atau 66,7\%. Dengan statusnya tersebut memudahkan ibu-ibu berpartisipasi dalam kunjungan imunisasi di Posyandu.

Selanjutnya, dari hasil analisis univariat, untuk aspek pengetahuan ibu diperoleh hasil bahwa hampir keseluruhannya yaitu sebanyak 72 responden atau 92,30\% ibu-ibu di Posyandu Tahun 2020 kurang memiliki pengetahuan tentang imunisasi. Pengetahuan ibu tentang imunisasi di Posyandu berhubungan secara bermakna dengan ketidakhadiran ibu-ibu di Posyandu. Semakin baik pengetahuan ibu semakin serong mereka hadir ke Posyandu. Faktor pendidikan para ibu juga menjadi penentu lebih sering hadir ke Posyandu [Notoatmodjo (2012), dll.].

Pada aspek sikap diperoleh hasil yang berbeda bahwa juga menunjukkan hasil bahwa sebagian besar responden memiliki sikap negatif terhadap kunjungan imunisasi di Posyandu tahun 2020, yaitu sebanyak 65 responden atau 83,30\%, sisanya bersikap positif. Sikap merupakan reaksi atau respon yang masih tertutup dari seseorang terhadap suatu stimulus atau objek. Suatu sikap belum otomatis terwujud dalam suatu tindakan. [Notoatmodjo (2012), dll.].

Berkaitan dengan aspek dukungan keluarga, diperoleh hasil bahwa sebagian besar responden yang mendapat dukungan dari keluarganya untuk melakukan kunjungan imunisasi di Posyandu tahun 2020 sebanyak 66 responden atau 84,60\%. Dukungan keluarga merupakan salah satu elemen penguat (reinforcing) bagi terjadinya perilaku kesehatan seseorang atau masyarakat. Dalam struktur masyarakat Indonesia yang paternalistik, peranan suami atau orang tua, keluarga dekat si ibu sangat menentukan dalam pemilihan tempat pelayanan kesehatan [Reihana \& Duarsa (2016), Notoatmodjo (2012), dll.].

Hasil dari analisis bivariat diperoleh bahwa ibu-ibu yang memiliki pengetahuan yang baik tentang imunisasi dan ikut berpartisipasi dalam kunjungan imunisasi 
adalah sebanyak 4 orang (9,1\%), sementara ibu yang memiliki pengetahuan kurang tetapi tetap ikut berpartisipasi dalam kunjungan imunisasi sebanyak 40 orang atau 90,1\%. Adapun ibu yang memiliki pengetahuan baik tetapi tidak ikut berpartisipasi dalam kunjungan imunisasi sebanyak 2 orang atau 5,9\%. Selanjutnya, ibu yang pengetahuan imunisasinya kurang dan juga tidak ikut berpartisipasi dalam kunjungan imunisasi sebanyak 32 orang atau 94,1\%. Tetapi dari hasil uji Chi-Square hasilnya tidak berpengaruh.

Hasil tersebut menunjukkan bahwa pengetahuan yang dimiliki oleh individu merupakan salah satu faktor internal yang keikutsertaan dalam pelayanan kesehatan. Pengetahuan merupakan domain yang sangat penting untuk terbentuknya tindakan seseorang. Pengetahuan diperlukan sebagai dukungan dalam menumbuhkan rasa percaya diri maupun sikap dan perilaku seseorang [Notoatmodjo (2012), Nafsiah, dkk. (2016), Muninjaya (2004), dll.].

Selanjutnya, dari hasil analisis terkait dengan pengaruh sikap ibu terhadap kunjungan imunisasi diperoleh hasil bahwa ibu-ibu yang memiliki sikap yang positif dan ikut berpartisipasi dalam kunjungan imunisasi adalah sebanyak 6 orang (13,6\%), sementara ibu yang memiliki negatif tetapi tetap ikut berpartisipasi dalam kunjungan imunisasi sebanyak 38 orang atau 86,4\%. Adapun ibu yang memiliki sikap positif tetapi tidak ikut berpartisipasi dalam kunjungan imunisasi sebanyak 7 orang atau 20,6\%. Selanjutnya, ibu yang sikapnya negatif dan juga tidak ikut berpartisipasi dalam kunjungan imunisasi sebanyak 27 orang atau 79,4\%. Hasil uji Chi-Square juga menunjukkan hasil tidak adanya pengaruh.

Hasil tersebut bebeda dengan sejumlah teori yang menyatakan pentingnya sikap terhadap partisipasi dalam pelayanan kesehatan. Sikap dapat mendorong seseorang untuk melakukan sesuatu yang dirasakan baik bagi dirinya. Sikap juga merupakan keteraturan tertentu dalam hal perasaan (afeksi), pemikiran (kognitif), dan predisposisi tindakan (konasi) seseorang terhadap suatu aspek di lingkungan sekitarnya. Sikap ibu untuk berpartisipasi aktif dalam kunjungan ke Posyandu merupakan wujud adanya kepentingan ibu untuk mendapatkan layanan kesehatan yang baik khususnya bagi bayi atau anaknya [Notoatmodjo (2012), Azwar (2013), Sunarti (2018), Septiani (2013), dll.]. 
Kemudian hasil analisis mengenai pengaruh dukungan keluarga terhadap partispasi kunjungan imunisasi ibu diperoleh hasil bahwa sebanyak 38 orang $(86,4,6 \%)$, sementara yang tidak mendapat dukungan tetapi tetap ikut berpartisipasi dalam kunjungan imunisasi sebanyak 6 orang atau 13,6\%. Adapun ibu yang mendapat dukungan keluarga tetapi tidak ikut berpartisipasi dalam kunjungan imunisasi sebanyak 28 orang atau 82,4\%. Selanjutnya, ibu yang tidak mendapat dukungan keluarga dan juga tidak ikut berpartisipasi dalam kunjungan imunisasi sebanyak 6 orang atau 17,6\%. Tetapi dari hasil uji Chi-Square hasilnya tidak berpengaruh.

Hasil penelitian tersebut berbeda dengan sesuai dengan teori bahwa dukungan keluarga (suami, orang tua, mertua maupun saudara lainnya) kepada ibu untuk ikut serta secara aktif dalam kegiatan pelayanan kesehatan di Posyandu, termasuk imunisasi. Keluarga merupakan sumber dukungan karena dalam hubungan keluarga tercipta hubungan yang saling mempercayai. Individu sebagai anggota keluarga akan menjadikan keluarga sebagai kumpulan harapan, tempat bercerita, tempat bertanya, dan tempat mengeluarkan keluhan-keluhan bilamana individu sedang mengalami permasalahan. Dukungan keluarga yang tinggi akan menjadikan seseorang lebih optimis dalam menghadapi masalah kesehatan dan kehidupan dan lebih terampil dalam memenuhi kebutuhan psikologi [Sitepu (2012), Sarafino (1997), Lubis, Namora \& Hasnida (2009), dll.].

\section{KESIMPULAN}

Tidak ada pengaruh Pandemi Covid-19 (aspek pengetahuan, sikap ibu, dan dukungan keluarga) terhadap kunjungan imunisasi di Posyandu Tanjungwangi, Desa Tanjungwangi, Kecamatan Cijambe Tahun 2020.

\section{DAFTAR PUSTAKA}

Azwar, S. (2013). Sikap Manusia. Yogyakarta: Penerbit Pustaka Pelajar. 
Dinkes Kabupaten Subang. (2019). Profil Kesehatan Kabupaten Subang. Subang: Dinkes Kab. Subang

Lubis, Namora dan Hasnida, L. (2009). Konseling Kelompok. Jakarta : Kencana Prenada Media Group

Muninjaya, A.A. (2004). Manajemen Kesehatan. Jakarta : Kedokteran EGC:

Nafsiah, M. (2016). Kebijakan pembangunan kesehatan 2014-2015 untuk penguatan program KB Nasional di era JKN. Prosiding. 2014:1-30.

Notoatmodjo. (2012). Promosi Kesehatan dan Ilmu Perilaku. Jakarta : Rineka Cipta

Reihana dan Duarsa, A.B.S. (2016). "Faktor-faktor yang berhubungan dengan tingkat partisipasi ibu untuk menimbang balita ke Posyandu di wilayah Puskesmas Panjang Bandar Lampung tahun 2010". Jurnal Kebijakan Kesehatan Indonesia, $5(2), 67-72$

Sarafino. E. P. (1997). Health Psychology: Biosychosocial Interactions. New York: John Wiley \& Sons. Inc.

Septiani, R. (2013). "Pengetahuan, sikap ibu hamil dan dukungan suami dengan keikutsertaan ibu hamil dalam kelas ibu hamil di Puskesmas Kota Metrolampung". Jurnal Kesehatan, IV(2), 408-415

Sitepu, S. (2012). "Hubungan Dukungan Keluarga Dengan Tingkat Kecemasan Pasien Pre Operasi Di Rumah Sakit Umum Haji Medan". Jurnal Kesehatan, 8(1).

Sunarti. (2018). "Hubungan Pengetahuan Dan Sikap Ibu Terhadap Partisipasi Dalam Kelas Ibu Balita Di Kelurahan Labibia Wilayah Kerja Puskesmas Labibia Kota Kendari Tahun 2018". Skripsi Tidak Dipublikasikan. Kendari: Poltekes Kendari.

Yurianto, A. (2020). Imunisasi di Tengah Pandemi Covid-19. [On line] www.covid19.go.id. [Diakses tanggal 10 Juni 2019]. 